DOI 10.4467/2543733XSSB.21.010.13803

\title{
ODWOLANIA DO KONSTYTUCJI RP Z 17 MARCA 1921 ROKU I EWOLUCJA ROZWIĄZAŃ KONSTYTUCYJNYCH W PROJEKTACH USTAWY ZASADNICZEJ RP Z LAT 90. XX WIEKU.
} ANALIZA ZAGADNIENIA NA WYBRANYCH PRZYKŁADACH

\author{
References to the Polish Constitution of March 17, 1921 \\ and the Evolution Constitutional Solution in the draft Constitution \\ of the Republic of Poland of the 1990s. \\ An Analysis of Selected Examples
}

Summary

The Polish constitutional drafts from the 1990s were one of the source texts of the 1997 Constitution of the Republic of Poland. Some of them tried very hard to refer to the solutions of the Polish Constitution of 1921. The article carried out an analysis to what extent the individual constitutional drafts referred to the solutions of the 1921 Constitution. The analysis of constitutional drafts and their similarities to the solutions of the 1921 Constitution were carried out on the basis of comparisons regarding, among others, the parliament, the president of Republic of Poland and legislative initiative.

Keywords: constitution, constitutional drafts, parliamentary clubs, Sejm, Constitutional Committee of the National Assembly, Polish Constitution 1921

Słowa kluczowe: konstytucja, projekty konstytucyjne, kluby parlamentarne, Sejm, Komisja Konstytucyjna Zgromadzenia Narodowego, Konstytucja 1921

Formalnie 2 kwietnia 2020 roku mijają 23 lata, odkąd Konstytucja RP z 1997 roku jest obowiązującą ustawą zasadniczą w Polsce. W nowej rzeczywistości politycznej, w której przyszło państwu polskiemu funkcjonować po 1989 roku, a zatem po symbolicznym opadnięciu żelaznej kurtyny, na tekst nowej konstytucji restytuowana w grudniu 1990 roku 
Rzeczpospolita musiała czekać niemal siedem lat. I chociaż był to wypatrywany dokument, to już po pierwszej dekadzie jego funkcjonowania nie tylko coraz głośniej część polskiej sceny politycznej argumentowała potrzebę jego zmiany, ale i szybko opracowano zastępczy projekt ${ }^{1}$. A budującej się demokracji w III RP w oparciu o zasady ujęte w Konstytucji z 2 kwietnia 1997 roku zarzucano m.in. petryfikację systemu komunistycznego oraz brak kontynuacji rozwiązań z II RP².

Jeżeli do oddalenia pierwszego zarzutu wydaje się wystarczające sięgnięcie np. do treści art. 11, 12 i 13 Konstytucji RP z 2 kwietnia 1997 roku, gwarantujących wolność tworzenia i funkcjonowania partii politycznych i związków zawodowych, jak i do argumentów historycznych - opisanych w publikacjach będących wynikiem swobody prowadzenia badań naukowych ${ }^{3}$, to w przypadku drugiego zarzutu niezbędne jest przeprowadzenie analizy badawczej.

Symbolem demokracji w II Rzeczpospolitej była m.in. jej Konstytucja z 17 marca 1921 roku. Chociaż, podobnie jak obecna ustawa zasadnicza RP z 1997 roku, nie była triumfalnie przyjęta przez część aktorów ówczesnej sceny politycznej - np. krytyczne stanowisko wobec Konstytucji RP z 1921 roku zajmował zarówno Józef Piłsudski ${ }^{4}$, jak i Bezpartyjny Blok Współpracy z Rządem, utworzony w 1927 roku $^{5}$ - to była ona uznawana za dzieło kompromisu politycznego, w którym upatrywano fundament odrodzonego państwa polskiego ${ }^{6}$. Widząc tak silnie zarysowaną parabolę pomiędzy zarówno historią procedowania obu ustaw konstytucyjnych, jak i ich późniejszymi politycznymi dziejami, podjęta została próba odnalezienia w rozwiązaniach konstytucyjnych z 1921 roku inspiracji do projektów konstytucyjnych Rzeczpospolitej z lat 90. XX wieku. Wspomniane projekty ustawy zasadniczej przyszłej III RP były bez wątpienia pewną podstawą mającej zostać uchwaloną konstytucji Rzeczpospolitej, miały też wyznaczać m.in. kierunki aksjologiczne w przyszłej umowie obywatelskiej Polaków.

\footnotetext{
${ }^{1}$ W trzynaście lat po ogłoszeniu Konstytucji RP z 1997 roku opracowany został przez Prawo i Sprawiedliwość w 2010 roku projekt nowej konstytucji RP, który zdaniem jej twórców, miał zastapić obowiązującą ustawę konstytucyjną. Partia ta już w 2009 roku w swoim programie zamieściła informacje o potrzebie zmiany Konstytucji z 1997 roku, co motywowano m.in. jej postkomunistycznym rodowodem. Zob. Polska nowoczesna, Polska solidarna, Polska bezpieczna. Program Prawa i Sprawiedliwości, Kraków 2009, s. 41.

${ }^{2}$ Ibidem, s. 7.

${ }^{3}$ Zob. m.in.: J. Karpiński, Ustrój komunistyczny $w$ Polsce, ANEKS, 1985; M. Kallas, A. Lityński, Historia ustroju i prawa Polski Ludowej, 2000; R. Matyja, Państwowość PRL w polskiej refleksji politycznej lat 1956-1980, Kraków-Nowy Sącz, 2007; Courtois, N. Werth, J. L. Pannè, A. Paczkowski, K. Bartosek, J. L. Margolin, Czarna księga komunizmu. Zbrodnie, terror, prześladowania, Warszawa 1999; K. Labędź, M. Mikołajczyk, Opozycja w systemach demokratycznych i niedemokratycznych, Kraków 2001; W. Bednarski, H. Głębocki, M. Korkuć, F. Musiał, J. Szarek, Z. Zbylewski, Komunizm w Polsce. Zdrada, zbrodnia, zakłamanie, zniewolenie, Kraków 2005; J. Borowiec, D. Iwaneczko (red.), Wybory '89 w Polsce południowo-wschodniej w dokumentach SB, Warszawa-Rzeszów 2009; G. Baziur, Wierni Polsce Niepodległej. Antykomunistyczna konspiracja młodzieżowa w województwie krakowskim w latach 1945-1956, Kraków 2010; J. Kwiek, Grudzień 1970 roku w Krakowie w świetle dokumentów. Przebieg wydarzeń i konsekwencje, Kraków 2012 i dalej.

${ }^{4}$ Zob. J. Piłsudski, Pisma zbiorowe, T. V, Warszawa 1937, s. 288-292.

${ }_{5}^{5}$ Zob. Stenogram z 18 posiedzenia Sejmu Rzeczpospolitej Polskiej z dnia 3 marca 1931 r., Warszawa, s. 3-94.

${ }^{6}$ Zob. G. Simon, Zagadnienie społeczne w konstytucji polskiej, Warszawa 1928, s. 5-7; W. Witos, Dzieła wybrane. Moje wspomnienia, T. 2, Warszawa 1990, s. 178-181; M. Kallas, Historia ustroju Polski X-XX w., Warszawa 1999, s. 308-311.
} 
Celem artykułu jest - poprzez analizę przyjętych przez Komisję Konstytucyjną Zgromadzenia Narodowego RP projektów konstytucyjnych z lat 90. XX wieku - opracowanie odpowiedzi na pięć pytań badawczych. Po pierwsze, czy i w jakim rozmiarze poszczególni twórcy wspomnianych projektów konstytucyjnych czerpali doświadczenia z klauzul Konstytucji RP z 1921 roku? Po drugie, czy sięgając do rezerwuaru spuścizny pierwszej pełnej polskiej konstytucji w XX wieku, architekci wspomnianych projektów ograniczyli się tylko do recypacji określonych rozwiązań, czy też były one źródłem dla nowych norm prawnoustrojowych? Bądź tylko deklarowaną wartością, która w finalnym zapisie projektu konstytucyjnego nie odnalazła żadnego ujęcia. Po trzecie, jaka była koncepcja, obraz naczelnych organów ustawodawczych w odradzającym się demokratycznym państwie polskim po 1989 roku, a wraz z tym, czy i w jakim wymiarze był uwzględniony suweren jako źródło inicjatywy ustawodawczej? Czy można w odniesieniu do tego zagadnienia wyznaczyć wspólne wektory z Konstytucją z 1921 roku, które pomimo upływu blisko osiemdziesięciu lat od uchwalenia Konstytucji z 1997 roku nadal mogły być rozwiązaniami aktualnymi. Po czwarte, jakiego urzędu prezydenckiego w Polsce w latach 90. XX w. oczekiwano? Czy miał być on kopią norm ustrojowych znanych Polakom z małej Konstytucji z 1992 roku, czy też efektem rozwiązań przejętych z kojarzonej z reżimem demokratycznym Konstytucji z 1921 roku. Po piąte, na podstawie zebranych wniosków z przeprowadzonych $\mathrm{z}$ analiz niezbędna będzie odpowiedź na pytanie, dlaczego projekty konstytucyjne z lat 90. XX wieku miałyby nawiązywać do regulacji ujętych w Konstytucji z 1921 roku? Jaki zysk przyniosłoby autorom projektu, jak i Polakom, sięgnięcie po takie rozwiązania?

Chociaż podstawą do przeprowadzenia analizy badawczej było wszystkich siedem zgłoszonych do Komisji Konstytucyjnej Zgromadzenia Narodowego RP projektów, to opisane wnioski w niniejszym artykule dotyczą - zdaniem autora - najciekawszych, nowatorskich, jak i najbardziej zbieżnych z tematem opracowania rozwiązań, jakie zostały zaprezentowane w poszczególnych projektach. Oczywiście, w mniejszym stopniu w artykule zostały zauważone i te rozwiązania, które były rozbieżne $\mathrm{z}$ tematem badawczym artykułu.

\section{Wstęp}

Kiedy 15 listopada 1989 roku Lech Wałęsa, ówczesny przewodniczący NSZZ ,Solidarność", przemawiał przed połączonymi Izbami Kongresu Stanów Zjednoczonych, rozpoczął swój odczyt od zwrotu: „We people”, co słusznie zostało przethumaczone w przekazie telewizyjnym jako: „My naród”. Wydaje się, że po 1989 roku - pomimo tworzenia i realnego funkcjonowania ustroju politycznego ${ }^{7} \mathrm{~W}$ Rzeczypospolitej - nie było tak częstych sytuacji, kiedy wypowiedź lidera społeczno-politycznego była werbalizacją rzeczywistych odczuć większości Polaków.

W czwartym wersie preambuły Konstytucji RP z 2 kwietnia 1997 roku prawodawca, identyfikując suwerena i wypowiadając się w jego imieniu, użył zwrotu: My Naród Polski

\footnotetext{
${ }^{7}$ Autor w niniejszym artykule zamiennie będzie wykorzystywał zwroty: ustrój polityczny i reżim polityczny.
} 
- wszyscy obywatele Rzeczypospolitej ${ }^{8}$. Pomimo iż zwrot ten nie jest spójny pod względem prawnym, to wskazuje dysponenta władzy zwierzchniej w RP, który poprzez przypisane mu uprawnienia ustanowił tekst konstytucji, będącej w oczekiwaniu suwerena prawami podstawowymi dla państwa9.

W obu przypadkach powołano się na głos narodu polskiego, który wówczas po raz pierwszy od 1947 roku mógł nie tylko swobodnie się wypowiedzieć, ale przede wszystkim mógł być wysłuchany, a jego głos - a właściwie wola - zaważyły na wynikach referendum konstytucyjnego z maja 1997 roku $^{10}$.

Zanim jednak w preambule konstytucyjnej III Rzeczpospolitej zamieszczono finalne wskazanie dla obywateli, by: Wszyscy, którzy dla dobra Trzeciej Rzeczpospolitej tę Konstytucję będa stosowali (...) czynili to, dbając o zachowanie przyrodzonej godności człowieka (...) prawa do wolności i obowiazku solidarności z innymi, a poszanowanie tych zasad mieli za niewzruszona postawę Rzeczypospolitej Polskiej, to we fragmencie wcześniejszym tego samego tekstu ustawodawca, wymieniając wartości, na których opisywana konstytucja była formowana, wspomniał o nawiązaniu do najlepszych tradycji Pierwszej i Drugiej Rzeczypospolitej i o zobowiqzaniu do przekazania przyszłym pokoleniom wszystkiego, co cenne $(. . .)^{11}$.

Bez wątpienia doświadczenia historyczne są dla współczesnego narodu polskiego, zarówno czynnikiem kształtującym jego świadomość społeczną ${ }^{12}$ czy pryzmatem, poprzez który formowany jest np.: katalog interesów narodowych $\mathrm{RP}^{13}$, jak i prawnoustrojową spuścizną, wywierającą realny wpływ na kształt ustrojowo-polityczny współczesnej Polski ${ }^{14}$. W pewnym uproszczeniu można stwierdzić, iż doświadczenia historyczne mogą dopomóc: tak w określeniu, jakich wartości nie należy uznawać i do jakich wartości zgłaszany jest akces.

Konsekwencją przemian prawnoustrojowych w pojałtańskiej wschodniej Europie było m.in. opracowanie i uchwalenie niemal dwudziestu nowych ustaw zasadniczych. Naturalnym etapem realizacji trzeciej fali demokracji było nie tylko wprowadzanie zmian prawnoustrojowych $\mathrm{w}$ tych państwach, ale i odpowiedź na pytanie o ciągłość prawną bytów politycznych, powstałych suwerennie po 1989 roku.

Trzeba przyznać, iż w tej przestrzeni każde z państw byłego bloku komunistycznego wypracowywało swoje własne rozwiązanie. Na przykład tzw. casus łotewski polegał na przywróceniu konstytucji z listopada 1922 roku i uzupełnieniu jej treści o współczesne rozwiązania ${ }^{15}$. Z kolei tzw. casus litewski przyjął formułę powrotu przez Republikę Litwy

${ }^{8}$ Zob. Preambuła do Konstytucji RP z 2 IV 1997 r., Dz.U. 1997 nr 78 poz. 483 wraz z późn. zm. Dalej: Konstytucja RP z 2 IV 1997 r.

${ }^{9}$ Ibidem.

${ }^{10}$ Konstytucja RP z 2 IV 19997 r. została przyjęta na podstawie wyników przeprowadzonego w dn. 25 maja 1997 r. referendum konstytucyjnego, w wyniku którego 53,45\% głosujących opowiedziało się za jej przyjęciem.

${ }^{11}$ Preambuła do Konstytucji RP z 2 IV 1997 r.

${ }^{12}$ P. Tuleja (red. nauk.), Konstytucja Rzeczypospolitej Polskiej. Komentarz, Wolters Kluwer, Warszawa 2019, S. 23 .

${ }^{13}$ Biała Księga Bezpieczeństwa Narodowego Rzeczypospolitej Polskiej, BBN, Warszawa 2014, s. 9-15.

${ }^{14}$ M. Safjan (red. nauk.), Konstytucja Rzeczypospolitej Polskiej. Komentarz, T. 1, C.H. Beck, Warszawa 2016, s. 140-145.

${ }^{15}$ Konstytucja Republiki Łotwy z 7 XI 1922 r. wraz z jej późn. zm., http://libr.sejm.gov.pl/tek01/txt/konst/ lotwa.html (Data dostępu 15.01.2020 r.) 
do Konstytucji z 1938 roku po to tylko, by po chwili Rada Najwyższa Litwy ją uchyliła i zastąpiła nowym aktem prawnym, Konstytucją z 1992 roku $^{16}$.

W przypadku państwa polskiego problem ciagłości prawnej nie stanowił dla Rzeczypospolitej w latach 1989-1992 zarówno pierwszo-, jak i drugoplanowego wyzwania. Niezbędne jest stwierdzenie, że jednoznaczne rozwiązanie tego problemu nie było łatwe co najmniej z kilku powodów. Po pierwsze, efektem porozumień okragłostołowych (6 II-5 IV 1989 r.) był Sejm PRL X kadencji, tzw. Sejm kontraktowy, podczas kadencji którego nowelizowano kilkukrotnie Konstytucję PRL z 1952 roku ${ }^{17}$. Po drugie, polska spuścizna prawnoustrojowa, w przeciwieństwie do prawodawstwa innych państw europejskich, zna i praktykuje rozwiązanie tzw. małych konstytucji - aktów prawnych powoływanych w szczególnym czasie dla kraju i mających charakter tymczasowy, do chwili uchwalenia właściwego tekstu konstytucji. Po trzecie, należało odpowiedzieć sobie na pytanie, do którego tekstu konstytucji z II RP się odwołać? Czy do Konstytucji z 17 marca 1921 roku czy do Konstytucji z 23 kwietnia 1935 roku? W obu przypadkach tliło się zarzewie konfliktu społecznego oraz ryzyko - czego najbardziej w pierwszych miesiącach po Okragłym Stole obawiała się opozycja - wycofania się z układów okrągłostołowych przez stronę ówczesnej władzy ${ }^{18}$.

Osobnym aspektem, który był również brany pod uwagę, szczególnie pośród środowiska politycznego odwołującego się do tradycji II RP i silnie związanego z emigracją polityczną był Londyn, a właściwie Rząd Rzeczypospolitej Polskiej na Uchodźstwie w Londynie. Próba obrania wspomnianego kierunku wydawała się tym bardziej realna, że formalnie konstytucja RP z kwietnia 1935 roku nie została zniesiona przez powojenne polskie prawodawstwo komunistyczne. Jednak ostatecznie inicjatywa ta nie uzyskała w kraju żadnej realnej siły oddziaływania na bieżącą politykę polską.

Konsekwencją zarówno zdominowania polskiej sceny politycznej przez rozwiązania okrąłostołowe, jak i postępującego rozwoju demokratyzacji - czego dowodził pluralizm polityczny - było ogłoszenie tekstu małej Konstytucji z 1992 roku przez Sejm RP I kaden-

\footnotetext{
${ }^{16}$ Konstytucja Republiki Litwy z 25 X 1992 r. wraz z jej późn. zm., http://libr.sejm.gov.pl/tek01/txt/konst/ litwa-a.html (Data dostępu 15.01.2020 r.)

${ }^{17}$ Konstytucja PRL z 1952 r. wraz z jej późniejszymi zmianami do czerwca 1988 r. była nowelizowana: dwukrotnie w 1989 r., w 1990 r. trzykrotnie, w 1991 r. dwukrotnie i jednokrotnie w 1992 r. Zob. M. Kruk (opr.), Mała Konstytucja z komentarzem, Warszawa 1994, s. 4-7.

${ }^{18}$ Ryzyko, jakie wiązało się z obiema konstytucjami, wynikało z konotacji historycznych. Konstytucja z 17 marca 1921 r. została formalno-prawnie zniesiona w 1935 r. Natomiast, wbrew obowiązującym przepisom II RP, została przywrócona przez komunistyczną PKWN, a jej fragmenty zostały następnie włączone do tzW. małej Konstytucji RP z 1947 r. Niezbędne jest podkreślenie, iż opisane działanie polskich komunistów z PPR było przykładem deklaratywnego postępowania, które nie odnajdywało po 1947 r. żadnego faktycznego punktu odniesienia.

Natomiast Konstytucja RP z kwietnia 1935 r. nigdy nie została formalnie zniesiona w powojennej Polsce. Ponadto na jej podstawie był zorganizowany i funkcjonował Rząd Rzeczypospolitej Polskiej na Uchodźstwie w Londynie, wraz z Prezydentem RP. A zatem ciało polityczne, które nie było uznawane przez stronę rządową, będącą jednocześnie współsygnatariuszem porozumień okrągłostołowych z 1989 r.

Warto nadmienić, iż ostatecznie uchwałą Senatu z 16 IV 1998 r. wyrażono nie tylko wdzięczność organom państwa polskiego na uchodźstwie, ale i uznano ciagłość prawną II i III Rzeczpospolitej. Zob. m.in. Sprawozdanie Stenograficzne z 1 posiedzenia Zgromadzenia Narodowego w dniach 21, 22, 23 września 1994 r., Warszawa, 1994, s. 20-21; Uchwała Senatu Rzeczpospolitej Polskiej z dnia 16 IV 1998 r. o ciagłości prawnej między II a III Rzeczpospolitq Polska, M.P. z 1998 r., nr 12, poz. 200.
} 
$\mathrm{cji}^{19}$. Za rewers tego wydarzenia należy uznać rozpoczęcie przez niemal wszystkie liczące się ugrupowania polityczne w RP oraz inne podmioty życia społeczno-politycznego w kraju konstruowania projektów ustaw zasadniczych dla Rzeczypospolitej. W efekcie tych wysiłków w latach 1993-1994 do Komisji Konstytucyjnej Zgromadzenia Narodowego RP wniesionych zostało aż siedem projektów ustawy zasadniczej. Były to projekty: a) Lecha Wałęsy, ówczesnego Prezydenta RP; b) Klubu Parlamentarnego SLD; c) Komisji Konstytucyjnej Senatu I kadencji; d) Klubu Parlamentarnego PSL; e) Klubu Parlamentarnego KPN; f) Klubu Parlamentarnego Unii Demokratycznej oraz g) NSZZ „Solidarność” 20.

\section{Źródła ideowe projektów konstytucyjnych}

Projekty konstytucyjne złożone do Komisji Konstytucyjnej Zgromadzenia Narodowego RP związane były z tymi podmiotami polskiej sceny politycznej, które w czasie dwóch pierwszych kadencji Sejmu RP - czyli w latach 1991-1993 i 1993-1997 - były w większości w niej reprezentowane. Niektóre kluby parlamentarne dążyły do czynnego uczestnictwa w tak znaczącym wydarzeniu politycznym w kraju, tak by mieć wpływ na kreowanie kształtu ustrojowego przyszłej III Rzeczpospolitej. Rezultatem tego było zawarcie w projektach konstytucyjnych określonych rozwiązań oraz wskazanie systemu aksjologicznego, na jakim przyszła konstytucja miała się opierać; było to pochodną tak ideowych koncepcji poszczególnych partii i ruchów społecznych z lat 80. XX wieku, jak i konsekwencją obciążenia historycznego Polaków z lat 1944-1989.

W projekcie konstytucyjnym zaproponowanym przez Komisję Konstytucyjną Senatu I kadencji można było - zdaniem przedkładających - wyróżnić trzy najbardziej charakterystyczne cechy. Po pierwsze, system aksjologiczny, który został przyjęty za podstawę wniesionego projektu, zasadzał się na wartościach chrześcijańskich, które - w ocenie jego twórców - od pokoleń ksztattowaty wzorce życia w polskiej wspólnocie państwowej ${ }^{21}$. Argumentacją mającą dodatkowo wesprzeć proponowane rozwiązanie było odniesienie do historii polskiej, w której wartości chrześcijańskie miały: a) stanowić najgłębszą treść kultury, b) ukształtować tożsamość narodu, c) stanowić, przekazywane pokoleniowo, dziedzictwo ${ }^{22}$. Niebagatelnym wsparciem forsowanego pomysłu, który mógł utwierdzić przedstawiających projekt w słuszności, były dane statystyczne, według których w 1994 roku blisko 94\% Polaków deklarowało wiarę chrześcijańską. Zatem niebezzasadne mogło być pytanie postawione przez autorów projektu: Jaki inny system wartości miałby wejść w miejsce systemu wartości chrześcijańskich? Zmiana systemu wartości leżacego u podstaw aksjologii konstytucji oznaczać by musiała chęć zmiany tożsamości narodu ${ }^{23}$.

Drugim zagadnieniem, które silnie wpłynęło na rozwiązania zaproponowane w projekcie senackim, były polskie tradycje konstytucyjne, które zostały wkomponowane w wy-

${ }^{19}$ P. Tuleja, Mała Konstytucja na tle innych źródet prawa konstytucyjnego, [w:] P. Sarnecki (red.), Zarys ustroju państwowego Polski. Zagadnienia podstawowe małej Konstytucji, Kraków 1993, s. 7-16.

${ }^{20}$ R. Chruściak, Projekty Konstytucji 1993-1997, cz. 1, Wyd. Sejmowe, Warszawa 1997, s. 5-35.

${ }^{21}$ Wypowiedź Alicji Grześkowiak podczas pierwszego czytania projektów konstytucyjnych na posiedzeniu Zgromadzenia Narodowego we wrześniu 1994 r., [w:] Sprawozdanie Stenograficzne z 1 posiedzenia, s. 26-31.

${ }^{22}$ Ibidem.

${ }^{23}$ Ibidem. 
mogi nowoczesnego państwa demokratycznego ${ }^{24}$. Sięgnięcie po rozstrzygnięcia nawiązujące do polskiej linii konstytucjonalizmu - szczególnie trzech Konstytucji: z 3 maja 1791 roku, 17 marca 1921 roku i z 23 kwietnia 1935 roku - miało być cechą (wolą) niepodległego $\mathrm{kraju}^{25}$, który pod wpływem rozwoju cywilizacyjnego i społecznego, dostosował ówczesne rozwiązania prawnoustrojowe do współczesnych potrzeb. Autorzy projektu konstytucyjnego, podkreślając wolę nawiązania do spuścizny prawnoustrojowej Rzeczypospolitej, jednoznacznie zaakcentowali dążność do potrzeby konstytucyjnego zabezpieczenia demokratycznego reżimu politycznego. Odpowiedzią na to wyzwanie miało być powstanie szeregu instytucji, których uruchomienie stanowiłoby gwarancję ciągłości ustrojowej RP. Proponowanymi rozwiązaniami były: konstytucjonalizacja zasady suwerenności narodu, podziału i równoważenia się władz, pluralizmu politycznego czy wolności działania wspólnot innych niż państwowe ${ }^{26}$.

Ostatnią, trzecią cechą znamienną projektu senackiego było przyjęcie koncepcji równoważenia się władz politycznych w Rzeczpospolitej i dążność do ich harmonijnej współpracy. Władza ustawodawcza miała m.in. wzorem rozwiązań konstytucyjnych z II RP znajdować się pośród dwuizbowego parlamentu, uwzględniającego i utrzymującego istnienie Senatu, przywróconego w 1989 roku. Na czele władzy wykonawczej miał stać prezydent, a realizowana byłaby ona przez premiera kierującego rządem. Natomiast władza sądownicza miała pozostawać w gestii niezależnych i niezawisłych sądów. Efektem tak zarysowanego układu wzajemnie równoważących się sił władzy było odrzucenie koncepcji przewagi jednej z nich nad drugą, gdyż w ocenie autorów projektu mogłoby to mieć skutki negatywne na zachowanie bezpiecznego oddziaływania władz publicznych, tak na prawa i wolności obywatelskie, jak i na reżim ustrojowy państwa, demokrację ${ }^{27}$.

Projekt konstytucyjny wniesiony przez klub parlamentarny PSL wraz z innymi kołami poselskimi do Komisji Konstytucyjnej Zgromadzenia Narodowego był - w ocenie jego autorów - emanacją zarówno tradycji polskiego parlamentaryzmu, jak i udziału ruchu ludowego w kreowaniu państwowości polskiej ${ }^{28}$. Architekci projektu, w przeciwieństwie do propozycji senackiej, nie wskazywali na żadne szczególne cechy bądź wartości, które by miały stać się ideowym fundamentem proponowanego aktu prawnego. Jednak, co zostało podniesione przez partię ludową, nie bagatelizowała ona polskiej tradycji poszanowania godności człowieka, konsekwencją czego miał być rozbudowany katalog konstytucyjny, opisujący prawa i wolności obywatelskie.

Autorzy złożonego do Komisji Konstytucyjnej ZN projektu Konfederacji Polski Niepodległej nie kryli swojego dążenia do przemodelowania - dotychczas utrwalonego w polskiej nauce prawno-ustrojowej, wzorca konstytucji. Posiłkując się postanowieniami wywodzącymi się z art. 125 Konstytucji RP z 1921 roku, wskazywali nie tyle na niezbędną

\footnotetext{
${ }^{24}$ Ibidem, s. 28.

${ }^{25}$ Zapewne odniesienie przewidujące dążność państwa do kontynuacji tradycji konstytucyjnej i postrzeganie tego zachowania jako cechy niepodległego, suwerennego kraju było parabolą do doświadczeń przymusu dla polskiego systemu ustrojowego $\mathrm{z}$ lat 1952-1989, kiedy recypowano rozwiązania m.in. konstytucyjne, np. w postaci Rady Państwa PRL. Zob. T. Sypniewski, Rada Państwa w systemie organów władzy państwowej Polski Ludowej (1947-1989), Toruń 2010.

${ }^{26}$ Wypowiedź Alicji Grześkowiak, s. 29.

${ }^{27}$ Ibidem, s. 30.

${ }^{28}$ Wypowiedź Aleksandra Łuczaka podczas pierwszego czytania projektów konstytucyjnych na posiedzeniu Zgromadzenia Narodowego we wrześniu 1994 r. [w:] Sprawozdanie Stenograficzne, s. 31.
} 
potrzebę rewizji tego aktu prawnego co 25 lat, ile na przymus opracowania takiej konstytucji, która powinna trwać, powinna działać, powinna normować nasze wspólne sprawy przez przynajmniej pierwsze ćwierćwiecze następnego stulecia-następnego tysiaclecia ${ }^{29}$. Zatem, w opinii przedkładających, miałaby to być konstytucja, która będzie wynikiem patrzenia się w przyszłość i będzie szukać takich rozwiazań, które będa pasowaty do rzeczywistości przyszłej, a nie starać się (...) poprawiać przeszłośćc ${ }^{30}$.

Konsekwencją przyjętego wektora rozwiązań było odrzucenie przez KPN dwóch spuścizn. Po pierwsze, modelu parlamentaryzmu XIX-wiecznego, który w ich ocenie nadal funkcjonował w XX w. i był źródłem tak w Europie, jak w Polsce kryzysu parlamentarnego, a nawet demokracji ${ }^{31}$. Drugim postulowanym zachowaniem było odcięcie się - co było zgodne z antykomunistyczną postawą ideowo-polityczną KPN - od recypacji jakichkolwiek rozwiązań prawnoustrojowych z lat 1944-1989. Następstwem tego było sięganie w swoich propozycjach zarówno do doświadczeń z Konstytucji marcowej z 1921 roku, jak i kwietniowej z 1935 roku $^{32}$. Jednak przede wszystkim wzorem dla przedkładanego projektu była konstytucja USA jako przykład funkcjonalnej ustawy zasadniczej, pozbawionej niepotrzebnych deklaracji ideowych czy politycznych. Niemniej zawierająca model funkcjonowania państwa i mechanizmy sprawowania władzy.

Klub Parlamentarny Sojuszu Lewicy Demokratycznej, uzasadniając przedłożony do Zgromadzenia Narodowego projekt ustawy zasadniczej, stwierdził, iż jest on wyrazem myślenia ustrojowego wielu pokoleń ludzi lewicy, nawiazuje do myślenia lewicy demokratycznej, do myśli socjaldemokratycznej33. Dodatkowo, opisując źródła prawnoustrojowe swojego projektu, członkowie SLD przyznali, że często odnosi się on do demokratycznych i liberalnych treści Konstytucji RP z 1921 roku. Miejscami nawet dostownie powtarza jej sformułowania ${ }^{34}$. Argumentując złożony projekt konstytucyjny do ZN, członkowie tego klubu parlamentarnego bardzo mocno podkreślali, że nie dążą do konstytucji, która byłaby manifestem politycznym, czy dokumentem ideologicznym ${ }^{35}$. Wtórnym następstwem złożonej deklaracji było optowanie autorów projektu za włączeniem do tekstu przyszłej konstytucji szerokiego katalogu demokracji bezpośredniej, czyli: a) referendum, b) inicjatywy ludowej, c) weta ludowego ${ }^{36}$.

\footnotetext{
${ }^{29}$ Wypowiedź Leszka Moczulskiego podczas pierwszego czytania projektów konstytucyjnych na posiedzeniu Zgromadzenia Narodowego we wrześniu 1994 r. [w:] Sprawozdanie Stenograficzne, s. 35 i in.

${ }^{30}$ Ibidem.

${ }^{31}$ Ibidem.

${ }^{32}$ Przykładem sięgnięcia przez KPN po rozwiązania konstytucyjne z 1935 r. może być np. treść art. 5, w którym Sejm za jego działalność obciążono odpowiedzialnością (...) wobec Boga, historii i narodu za losy Rzeczypospolitej. Niemal tak samo brzmiąca norma konstytucyjna ujęta została w art. 2 ust. 2 Konstytucji z 23 IV 1935 r. Zob. Ustawa konstytucyjna z dnia 23 kwietnia 1935 r., Dz. U. RP z 24 IV 1935 r., nr 30, poz. 227; P. Skorut, Bezpieczeństwo państwa, niepodległość i nienaruszalność terytorium Rzeczypospolitej w projekcie konstytucji RP opracowanym przez kluby parlamentarne Konfederacji Polski Niepodległej w 1993 roku oraz przez Sojusz Lewicy Demokratycznej z 1994 roku. Analiza zagadnienia na wybranych przykładach, [w:] P. Łubiński (oprac. nauk.), Niepodległa Polska. Bezpieczeństwo i polityka w latach 1918-2018, Kraków 2018, s. 302, 304-308.

${ }^{33}$ Wypowiedź Jerzego Jaskierni podczas pierwszego czytania projektów konstytucyjnych na posiedzeniu Zgromadzenia Narodowego we wrześniu 1994 r. [w:] Sprawozdanie Stenograficzne, s. 43.

${ }^{34}$ Projekt Konstytucji Rzeczypospolitej Polskiej wniesiony przez klub parlamentarny SLD w dn. 9 V 1994 r., druk ZN/2, www.bs.sejm.gov.pl/F?func=direct\&doc_number=000030488 (data dostępu 12.01.2020 r.)

${ }^{35}$ Wypowiedź Jerzego Jaskierni podczas pierwszego czytania projektów konstytucyjnych..., s. 46.

${ }^{36}$ Ibidem.
} 


\section{Tabela nr 1}

\begin{tabular}{|c|c|c|}
\hline \multicolumn{3}{|c|}{ Projekty konstytucji RP z lat 1993-1994 } \\
zlożone do Komisji Konstytucyjnej Zgromadzenia Narodowego \\
\hline Lp. & Przedkładający & Data zlożenia projektu \\
\hline 1 & Lech Wałęsa, Prezydent RP & 6 V 1994 r. \\
\hline 2 & Klub Parlamentarny SLD & 9 V 1994 r. \\
\hline 3 & Komisja Konstytucyjna Senatu I kadencji & 24 III 1993 r. \\
\hline 4 & $\begin{array}{c}\text { Klub Parlamentarny PSL } \\
\text { Praz z Unią Pracy, Mniejszością Niemiecka, }\end{array}$ & 30 IV 1993 r. \\
\hline 5 & Klub Parlamentarny KPN & 30 IV 1993 r. \\
\hline 6 & Klub Parlamentarny Unii Demokratycznej & 9 V 1994 r. \\
\hline 7 & Projekt obywatelski: NSZZ „Solidarność” & 5 IX 1994 r. \\
\hline
\end{tabular}

Źródło. Opracowanie własne.

Najpóźniej, bo 5 września 1994 r., złożonym projektem do Komisji Konstytucyjnej Zgromadzenia Narodowego był dokument autorstwa NSZZ „Solidarność”, który przedstawiany był jako projekt obywatelski. We wstępnych słowach opisujących treść przedstawionej propozycji konstytucyjnej twórcy projektu zaznaczyli, iż tożsamości współczesnej Rzeczpospolitej należy doszukiwać się tylko w II RP, która była prawdziwie niepodległym państwem polskim $^{37}$. Następstwem tej myśli była refleksja powiązana z niewypowiedzianą wprost przestrogą: by konstytucja - jej tekst - nie była przypadkowa i nie była odzwierciedleniem bieżących układów politycznych. Albowiem jej ustalenia - jak słusznie przewidywano - miały na lata wyznaczyć ramy prawne funkcjonowania państwa i rozwoju $n a r o d u^{38}$. Zatem, zdaniem przedkładających, musiała przyszła konstytucja opierać się na silnym fundamencie aksjologicznym ${ }^{39}$.

Projekt obywatelski, w ocenie jego twórców, był silnie wsparty na trzech głównych wartościach: a) chrześcijańskich, b) patriotyczno-narodowych i c) społecznych.

W odniesieniu do wartości chrześcijańskich wskazano, że ich emanacją było zaproponowanie konstytucjonalizacji m.in. rozbudowanych praw człowieka i rodziny oraz oparcie rozwiązań ustrojowych na zasadach katolickiej nauki społecznej. Dalej dowodzono, że sięgnięcie po chrześcijańską koncepcję człowieka i społeczeństwa nie jest rozwiązaniem ograniczającym się jedynie do osób związanych z tym wyznaniem. W wartościach chrześcijańskich przedkładający projekt konstytucyjny upatrywali cechy humanitarne i otwarte,

${ }^{37}$ Wypowiedź Mariana Krzaklewskiego podczas pierwszego czytania projektów konstytucyjnych na posiedzeniu Zgromadzenia Narodowego we wrześniu 1994 r. [w:] Sprawozdanie Stenograficzne, s. 50.

${ }^{38}$ Ibidem.

${ }^{39}$ Ibidem. 
stanowiace fundament autentycznej demokracji leżacej u podstaw idei naturalnej i niezbywalnych praw człowiek ${ }^{40}$.

Drugim filarem aksjologicznym projektu obywatelskiego były wartości patriotyczne i narodowe, które miały być pomostem łączącym współczesny akt prawny z polską tradycją i konstrukcją ustrojową. Celem ich wykorzystania było - w opinii twórców projektu zabezpieczenie niepodległości kraju i podmiotowości obywateli.

Ostatnim istotnym nośnikiem ujętym w projekcie konstytucyjnym NSZZ „Solidarność” były wartości społeczne, które miały zostać włączone do praw socjalnych w przyszłym akcie prawnym, opartym na dialogu i solidarności partnerów społecznych ${ }^{41}$.

\section{Preambuly}

Punktem odniesienia, którego nie sposób pominąć w procesie komparatystyki projektów konstytucyjnych wobec Konstytucji RP z 17 marca 1921 roku, jest preambuła ${ }^{42}$. Ta część wstępna, opisana uroczystym językiem, poprzedzająca właściwy tekst konstytucyjny posiada w polskim dorobku ustrojowym bogatą, choć nie ciągłą spuściznę, sięgającą czasów 3 maja 1791 roku $^{43}$.

W przypadku Konstytucji marcowej z 1921 roku było to wprowadzenie - składające się z dwóch rozwiniętych zdań - zawierające nie tylko Invocatio Dei, które swoją wymową wprost nie odnosiło się do formuły wiary chrześcijańskiej ${ }^{44}$, ale i odwołanie do historycznych źródeł ustrojowych, czy podziękowań minionym pokoleniom ofiarnie walczącym w czasie półtorawiekowej niewoli ${ }^{45}$, jak i do nadziei na zapewnienie (...) sił moralnych i materialnych dla dobra (...) Rzeczypospolitej ${ }^{46}$.

Pośród siedmiu złożonych projektów konstytucyjnych do Komisji Konstytucyjnej ZN aż pięć zawierało preambułę, a dwa pozostałe - tj. projekt L. Wałęsy i KPN - rozpoczynały się bezpośrednio od artykułów konstytucyjnych. Trzeba przyznać, że żadna z propo-

${ }^{40}$ Ibidem, s. 51.

${ }^{41}$ Ibidem.

${ }^{42} \mathrm{O}$ niebagatelnym znaczeniu preambuły jako jednego z punktów odniesienia w opisywanym procesie porównawczym dowodzi m.in. zbieżność wyzwań historycznych, których efektem była Konstytucja z 17 marca 1921 r. i Konstytucja z 1997 r. Dodatkowo, w przypadku treści preambuły i jej załączania, pewną prawidłowość zauważył A. Gwiżdż, którego zdaniem zwykło się zamieszczać preambuły w konstytucjach tych państw, które dokonały przemian ustrojowych. Nie dotyczy to państw nordyckich. Zob. A. Gwiżdż, Wstęp do konstytucji, Warszawa, 1997, s. 168.

${ }^{43}$ Warto zaznaczyć, że pośród tekstów konstytucyjnych związanych z historycznymi polskimi bytami politycznymi tylko cztery z nich poprzedzone były preambułą. Były to Konstytucje z: 3 V 1791 r., 17 III 1921 r., 22 VII 1952 r. oraz 2 IV 1997 r. Zob. J. Kowecki (opr.), Konstytucja 3 Maja 1791. Statut Zgromadzenia Przyjaciót Konstytucji, Warszawa 1981, s. 81-82; A. Ajnenkiel, Polskie konstytucje, Warszawa 1991.

${ }^{44}$ Odmiennie od rozwiązania przyjętego w Konstytucji 3 maja z 1791 r., w której tekst preambuły rozpoczynał się do słów jednoznacznie odnoszących się do wiary chrześcijańskiej: W imię Boga w Trójcy Świętej Jedynego. Zob. P. Skorut, Odwolanie od Boga i wartości religijnych w ustawach zasadniczych Rzeczypospolitej Polskiej w XX wieku jako element bezpieczeństwa reżimu politycznego i kulturowego: analiza tematu w porównaniu z wybranymi przykładami konstytucji państw europejskich wXX wieku, [w:] R. Michalik (red. nauk.), Implementacja zasad religijnych w sferze politycznej, Zielona Góra 2016, s. 115-127.

${ }^{45}$ Ustawa z dnia 17 marca 1921 r. - Konstytucja Rzeczypospolitej Polskiej, Dz. P. 1921 nr 44, poz. 267 z późn. zm.

${ }^{46}$ Ibidem. 
nowanych treści uroczystego wstępu do projektu konstytucji nie była lustrzanym odbiciem rozwiązania z 1921 roku. Natomiast można stwierdzić, że zarówno projekt senacki, PSL, jak i NSZZ „Solidarność” w swojej treści nawiązywały do rozwiązań tekstowych zamieszczonych w preambule konstytucji marcowej z 1921 roku.

Spośród trzech wspomnianych wyżej projektów jedynie dwa, autorstwa Senatu i NSZZ „Solidarność”, wzbogaciły treść swojej preambuły, tak o odniesienie do Invocatio Dei, jak i do wartości religijnych.

Projekt senacki, podobnie jak preambuła marcowa z 1921 roku - składał się z dwóch rozbudowanych zdań. Początkowa fraza rozpoczynała się od inwokacji, właściwie przekopiowanej z pierwszej polskiej konstytucji w XX wieku: W imię Boga Wszechmogqcego! ${ }^{47}$. W kolejnej, wielokrotnie złożonej części elementem wspólnym dla obu dokumentów było odwołanie się do głosu narodu - który świadom podmiotowości, jak i historii swojej - zwracał się uroczyście do czytającego: My, Naród Polski ${ }^{48}$. W dalszych fragmentach omawianego senackiego projektu konstytucyjnego przywołano tradycję Konstytucji 3 maja oraz nadto odwołano się do tysiqcletnich dziejów, zwiqzanych z dziedzictwem chrześcijańskim, także do wysiłku pokolenia walczącego o niepodległość. Nowością, z oczywistych względów, nieznaną zapisowi konstytucyjnemu z 1921 roku było wspomnienie o pokojowym zrywie ,, Solidarności”.

Senacki projekt preambuły, podobnie jak i preambuła Konstytucji marcowej z 1921 roku, zwieńczony był nadzieją, że konstytucjonalizowane wartości staną się dla obywateli Rzeczypospolitej zabezpieczeniem odzyskanej wolności.

Projekt konstytucyjny przedstawiony przez klub parlamentarny PSL w odróżnieniu do propozycji przedłożonych przez inne kluby poselskie, zatytułował część wstępną, poprzedzającą treść konstytucji, zwrotem DEKLARACJA. To nieznane polskiej spuściźnie prawno-ustrojowej rozwiązanie w dalszej swojej formule naśladowało, wraz z uroczystym językiem, preambułę ${ }^{49}$.

Warto zaznaczyć, że w zaproponowanej czterozdaniowej deklaracji konstytucyjnej ludowcy, podobnie jak autorzy innych projektów, zawarli dość obszerne podziękowania (...) tym, którzy z nadzieja niepodległości Polski polegli na polach bitew, w powstaniach $i$ walce podziemnej ${ }^{50}$. Kolejnym odniesieniem było m.in. sięgnięcie przez twórców projektu po wizję przyszłej ojczyzny, której fundamentem zmian miała być konstytucja. Treść tego szczególnego aktu prawnego miała odrodzonej Rzeczypospolitej (...) zapewnić byt bezpieczny, a instytucjom Jej moc i trwałośc $c^{51}$.

Odmiennie od projektu PSL, przedstawione przez NSZZ „Solidarność” rozwiązanie konstytucyjne w uroczystej części wydzielonej, czyli w preambule, zaczynało się od zwrotu: My Naród Polski. Ta przeszczepiona fraza, wprost z preambuły Konstytucji RP z marca 1921 roku, jest jednym z dwóch przykładów - obok nawiązania do tradycji Konstytucji

\footnotetext{
${ }^{47}$ Projekt Konstytucji Rzeczypospolitej Polskiej uchwalony przez Komisję Konstytucyjnq Senatu I kadencji $w$ dniu 19 III 1993 r., druk ZN/3, https://bs.sejm.gov.pl/F?func=direct\&doc_number=000030489 (data dostępu 18.01.2020 r.)

48 Ibidem.

${ }^{49}$ Projekt Konstytucji Rzeczpospolitej Polskiej, wniesiony przez Klub poselski PSL w dniu 30 IV 1993 r., druk $Z N / 4$, https://bs.sejm.gov.pl/F?func=direct\&doc_number=000030489 (data dostępu 18.01 .2020 r.).

${ }^{50}$ Ibidem.

${ }^{51}$ Ibidem.
} 
3 maja - zastosowania paraboli przez autorów projektu z NSZZ „Solidarność” do konstytucji marcowej z 1921 r. Pozostała treść planowanej preambuły wspominała o historycznych dokonaniach narodu polskiego w walce nie tylko z najeźdźcami w czasie II wojny światowej, ale i o m.in. pokojowym zrywie solidarnościowym. Ciekawie zastosowanym rozwiązaniem, które pośrednio można powiązać z pierwszą polską konstytucją w XX wieku, jest invocatio Dei. Ujęte ono zostało na końcu proponowanego tekstu preambuły i włączone w wypowiedź suwerena, oznajmiającego o ustanowieniu Konstytucji III Rzeczpospolitej i posiłkującego się dodatkowo odwołaniem: (...) w Imię Bog $a^{52}$. Co może wydawać się interesujące, podobnie jak Konstytucja z 1921 roku, tak i tzw. projekt obywatelski autorstwa NSZZ „Solidarność” użył formuły odnoszącej się do Boga, która nie nawiązywała swoją treścią wprost do wiary chrześcijańskiej.

Omawiając treści preambuł zawartych w projektach konstytucyjnych RP, nie można pominąc propozycji Sojuszu Lewicy Demokratycznej. Jak zostało wcześniej wspomniane, autorzy w swoim projekcie wprost informowali tak o czerpaniu inspiracji z Konstytucji z 1921 roku, jak wręcz o powtarzaniu jej sformułowań. Zacytowana deklaracja klubu parlamentarnego SLD nie dotyczyła jednak preambuły, jak i - co wykazuje analiza tekstu projektu konstytucyjnego - większości jej treści. Projekt preambuły Sojuszu Lewicy Demokratycznej był pozbawiony jakiegokolwiek odniesienia do historii politycznej Polski, do przełomu z 1989 roku, jak i do wartości religijnych. Treść zaproponowanej preambuły, dość surowa i nierozbudowana w swojej formie, opisywała jedynie decyzję podjętą przez naród polski:

Naród polski, przyjmując w powszechnym głosowaniu projekt uchwalony przez demokratyczne Zgromadzenie Narodowe, nadaje sobie niniejszą Konstytucję Rzeczypospolitej Polskiej $^{53}$.

Tę prosta, acz czytelną w formie preambułę trudno jest zaliczyć do szczególnie oryginalnych rozwiązań. Zasugerowany przez SLD układ jej treści przypomina wykorzystane rozstrzygnięcia konstytucyjne z czasów przed 1939 rokiem. Np. w Konstytucji Republiki Łotewskiej z 1922 roku zapisano: Naród totewski, za pośrednictwem swych przedstawicieli, swobodnie wybranych do Zgromadzenia Konstytucyjnego, postanowit nadać sobie nastepujaca Konstytucję $e^{54}$. Podobny jest zapis preambuły konstytucyjnej Wolnego Państwa Pruskiego: Lud pruski nadat sobie przez swe konstytucyjne Zgromadzenie krajowe następująq Konstytucję, która niniejszym ogłasza się $e^{55}$.

\section{Urząd prezydencki}

Wszystkie projekty konstytucyjne zgłoszone do Komisji Konstytucyjnej ZN opowiadały się za utrzymaniem przywróconego w dniu 19 lipca 1989 roku urzędu prezydenckie-

${ }^{52}$ Konstytucja Rzeczypospolitej Polskiej. Projekt obywatelski NSZZ Solidarność, „Co tydzień Solidarność” wydanie specjalne, nr 12 (63), 1994, s. 1.

${ }^{53}$ Projekt Konstytucji Rzeczypospolitej Polskiej wniesiony przez klub parlamentarny SLD...

${ }^{54}$ Konstytucja Republiki Łotewskiej, [w:] J. Makowski, Nowe konstytucje, Warszawa 1925, s. 137.

${ }^{55}$ Konstytucja Wolnego Państwa Pruskiego z 30 XI 1920 r. [w:] J. Makowski, op. cit., s. 417. 
go, który następnie został potwierdzony w treści małej Konstytucji RP z 1992 roku. Zarysowana różnica pomiędzy poszczególnymi siłami politycznymi głównie skupiła się na postrzeganiu roli i zakresu oddziaływania tego urzędu tak na politykę wewnętrzną i zewnętrzną Rzeczypospolitej, jak i współpracy z innymi organami władzy publicznej.

Idea przywrócenia urzędu prezydenckiego w Polsce po 1952 roku, a przed 1989 rokiem, nie była politycznym novum ${ }^{56}$. Jednak odmiennie np. od rozwiązań w Czechosłowackiej Republice Socjalistycznej czy w Socjalistycznej Federacyjnej Republice Jugosławii, władze polityczne PRL nie zdecydowały się na reformę ustrojową państwa. Przywrócony urząd prezydencki w Polsce, jak i osoba pierwszego i jedynego Prezydenta PRL były nie tylko efektem okrąłłostołowego kompromisu politycznego z 1989 roku, ale i materializacją hasła Adama Michnika: Wasz prezydent, nasz premier $^{57}$.

Wraz z wyborem pierwszego prezydenta RP, Lecha Wałęsy, jak i rozpoczęciem procedowania nowej polskiej konstytucji otwarty został publiczny dyskurs ogniskujący się m.in. wokół kształtu urzędu prezydenckiego. Niestety, często formułowana argumentacja odnośnie do kompetencji instytucji pierwszego obywatela RP łączona była z osobą Wałęsy, którego autorytet doznawał w tym czasie erozji pośród społeczeństwa polskiego ${ }^{58}$.

W projekcie Lecha Wałęsy, oznaczonym przez Komisję Konstytucyjną ZN jako druk $\mathrm{nr}$ 1, instytucja prezydenta opisana została w osobnym podrozdziale, pośród trzynastu artykułów. Na ich to podstawie Prezydent RP miałby stać na czele władzy wykonawczej, którą by sprawował bądź bezpośrednio, bądź za pośrednictwem Rady Ministrów i członków rządu. Przyjęcie takiego rozwiązania nie było przykładem nawiązania do rozwiązań konstytucyjnych z 1921 roku, w których Prezydent RP był postrzegany jako organ sprawujacy władzę wykonawcza przez odpowiedzialnych przed Sejmem ministrów i podległych im urzędników ${ }^{59}$.

Dodatkowo w projekcie konstytucyjnym Wałęsy urząd prezydenta z upoważnienia ustawy mógł być odpowiedzialny za m.in.: a) wyrażenie zgody na zmianę granic oraz integralności państwa, b) zawarcie sojuszy, układów politycznych, wojskowych oraz pokoju oraz c) wypowiedzenie praw, wolności i obowiązków obywatelskich określonych w Konstytucji ${ }^{60}$. Trzeba przyznać, iż tak szeroka możliwość działania urzędu prezydenckiego była obca treści konstytucyjnej z 1921 roku. Chociaż Prezydentowi RP przypisano prawo zawierania umowy w imieniu Rzeczpospolitej z innymi krajami, to był on zobligowany do poinformowania o tym Sejmu. A w przypadku zmiany granic lub zawarcia przymierza musiał mieć zgodę izby niższej RP ${ }^{61}$.

${ }^{56}$ O planach przywrócenia urzędu prezydenckiego w PRL w 1976 r. przez Edwarda Gierka, ówczesnego I Sekretarza KC PZPR, wspomniał Józef Tejchma. Zob. Autoryzowany wywiad z Józefem Tejchma z dnia 11 marca 2002 r. [w:] P. Skorut, Front Jedności Narodu. Od narodzin idei do upadku politycznego pozoru, Wyd. Attyka, Kraków, 2015, s. 205.

${ }^{57}$ A. Michnik, Wasz prezydent, nasz premier. Potrzebny jest uklad nowy, możliwy do zaakceptowania przez wszystkie główne sity polityczne, „Gazeta Wyborcza”, 3 VII 1989 r., nr 40, s. 1.

${ }^{58}$ A. Michnik, Czy Watęa zagraża demokracji?, „Gazeta Wyborcza”, 14-15 XI 1992; J. Galarowicz, Dlaczego nie będę głosowat na Lecha Wałęsę?, „Głos”, 20-22 X 1995; J. Paradowska, Król Lew. Bilans Lecha Watęsy: 1990-95, „Polityka”, 25 XI 1995.

${ }^{59}$ Art. 43 Konstytucji RP z 17 marca 1921 r.

${ }^{60}$ Art. 60 ust. 3 pkt 1-3 Projektu konstytucji RP wniesionego przez Lecha Watese, oznaczonego przez Komisję Konstytucyjna Zgromadzenia Narodowego, jako druk ZN nr 1 [w:] R. Chruściak, Projekty Konstytucji 1993-1997, s. 57.

${ }^{61}$ Art. 49 Konstytucji RP z 17 marca 1921 roku. 
Co ciekawe, ten sam projekt przewidywał możliwość wydawania przez urząd prezydenta szerokiego wachlarza aktów prawnych, poprzez które realizowane byłyby kompetencje prezydenckie. Wymienionymi aktami urzędowymi miały być: a) rozporządzenia i zarządzenia wydawane na podstawie upoważnień określonych w konstytucji, ustawach i dekretach, b) decyzje wynikające z realizacji uprawnień oraz c) inne akty prawne ${ }^{62}$. Przyznanie tak szerokiej możliwości operowania aktami prawnymi zostało dodatkowo wzbogacone przez normę konstytucyjną, która przewidywała brak odpowiedzialności parlamentarnej i sądowej dla prezydenta za wydane akty urzędowe ${ }^{63}$.

Rozwiązaniem bardzo ciekawym, sięgającym do polskich doświadczeń historycznych z lat 1939-1945 - było zaproponowanie pośród prerogatyw prezydenckich uprawnienia do wyznaczenia w okresie stanu wojny przez pierwszego obywatela RP swojego następcy ${ }^{64}$.

Tzw. projekt prezydencki przewidywał, iż wybór na urząd prezydenta RP odbywać się powinien na podstawie głosowania pięcioprzymiotnikowego: powszechnego, równego, bezpośredniego, tajnego i bezwzględną większością ważnie oddanych głosów. A kandydaci na prezydenta mieli być wyznaczeni na trzy sposoby: a) poprzez zgłoszenie przez 500 tys. obywateli, b) zgłoszenie przez 136 posłów i senatorów, c) przez prezydenta kończącego urzędowanie ${ }^{65}$. Ten ostatni sposób wyznaczania kandydata na prezydenta był przykładem recypowania rozwiązania konstytucyjnego z 1935 roku $^{66}$.

Kadencja prezydencka, przeciwnie niż w Konstytucji z 1921 roku, miała trwać nie siedem, a pięć lat. To natomiast, co dodatkowo łączyło te dwa dokumenty, to ograniczenie sprawowania funkcji Prezydenta RP przez jedną osobę do dwóch kadencji.

Projekt konstytucyjny przedstawiony przez klub parlamentarny Unii Demokratycznej przewidywał, inaczej niż dokument Lecha Wałęsy, iż Prezydent RP miał wraz z Radą Ministrów sprawować władzę wykonawczą w Rzeczpospolitej. A zatem twórcy projektu uwzględnili w wykonaniu opisywanej władzy dwa równoważne organy. Konsekwencją takiej wymuszonej koegzystencji było zaprojektowanie zobowiązania, by określone w projekcie konstytucyjnym akty urzędowe wydawane przez Prezydenta RP - były kontrasygnowane przez Prezesa Rady Ministrów. Tym samym osoba premiera przejmowałaby odpowiedzialność za wydany akt przed Sejmem. Niezbędne jest nadmienić, iż w Konstytucji RP z 1921 roku akt urzędowy wydawany przez urząd prezydencki musiał być - dla utrzymania jego ważności - kontrasygnowany nie tylko przez Prezesa Rady Ministrów, ale i właściwego ministra. W ten sposób obaj podpisani brali odpowiedzialność za wydany akt prawny ${ }^{67}$.

W przeciwieństwie do regulacji konstytucyjnej z marca 1921 roku, w projekcie UD zawarto informację o przypisaniu urzędowi prezydenckiemu uprawnień do zarządzenia wyborów do Sejmu, Senatu i rad gminnych. Marcowa ustawa zasadnicza z 1921 roku nie wykazywała tej kompetencji prezydenckiej wobec izb parlamentarnych II RP, a tym bardziej wobec jednostek samorządu terytorialnego. Regulacja tych zagadnień była ujmowana

\footnotetext{
${ }^{62}$ Art. 61 ust. 3 pkt 1-3 Projektu konstytucji RP wniesionego przez Lecha Wałęse...

${ }^{63}$ Ibidem, art. 66 ust. 1.

${ }^{64}$ Ibidem, art. 126 ust. 5.

${ }^{65}$ Ibidem, art. 55 ust. 7.

${ }^{66}$ Art. 16 ust. 3 Konstytucji RP z 23 IV 1935 r.

${ }^{67}$ Art. 44 Konstytucji RP z 17 marca 1921 roku.
} 
dopiero na poziomie ordynacji wyborczej, w której Prezydent RP był wyznaczany jako organ należny do zarządzenia wyborów do Sejmu i Senatu ${ }^{68}$.

Projekt konstytucyjny Unii Demokratycznej wniesiony pod obrady Zgromadzenia Narodowego w swoich propozycjach daleki był również od rozwiązań Konstytucji marcowej z 1921 roku w aspekcie sposobu wyboru pierwszego obywatela RP. Przedłożona propozycja ustawy zasadniczej dla Rzeczpospolitej przewidywała przeprowadzenie pięcioprzymiotnikowych wyborów na urząd prezydencki, którego kadencja miała trwać pięć lat, z możliwością jednorazowej reelekcji.

W projekcie konstytucyjnym Klubu Parlamentarnego Sojuszu Lewicy Demokratycznej urząd prezydencki został głównie opisany w rozdziale III, pośród siedemnastu artykułów. Jednak najważniejszy zapis, informujący o konstytucyjnym postrzeganiu tego urzędu, został ujęty wśród tzw. artykułów podstawowych, gdzie określono, że Prezydent Rzeczpospolitej Polskiej jest najwyższym przedstawicielem Państwa Polskiego w stosunkach wewnętrznych $\mathrm{i}$ międzynarodowych ${ }^{69}$. Zapis ten nabierał dodatkowego znaczenia, kiedy był konfrontowany z inną projektowaną normą, przewidująca, iż Sejm jest najwyższym organem Państwa w zakresie ustawodawstwa, Rada Ministrów najwyższym organem w zakresie władzy wykonawczej, a niezawiste sqdy sprawuja wymiar sprawiedliwości $i^{70}$. Projekt wyprowadzenia urzędu prezydenckiego spośród dotychczas znanego w ustroju RP modelu trójpodziału władzy był nowością dla polskiego konstytucjonalizmu, dalece obcego rozwiązaniom konstytucyjnym z 1921 roku, do których Klub Parlamentarny SLD deklarował się nawiązywać.

Konsekwencją politycznej marginalizacji urzędu prezydenckiego względem pozostałych organów władz naczelnych RP było m.in. większe zaangażowanie osoby Prezesa Rady Ministrów w działania prezydenckie. Np. premier był zobowiązany do zawiadomienia Sejmu o przedłożonych Prezydentowi umowach międzynarodowych do ratyfi$\operatorname{kacji}^{71}$.

Omawiany projekt konstytucyjny, przeciwnie do Konstytucji z marca 1921 roku, przewidywał bezpośredni wybór Prezydenta RP w głosowaniu czteroprzymiotnikowym. Podobnie jak i propozycje konstytucyjne innych klubów poselskich, również projekt SLD optował za tym, by kadencja prezydencka trwała pięć lat. A samo sprawowanie urzędu mogło być realizowane tylko przez dwie kadencje.

\section{Projektowane organy parlamentarne}

Aleksander Hall na łamach „Gazety Wyborczej”, w niemal trzy lata od rozpoczęcia rozmów okragłostołowych, dowodził, iż demokracja w Polsce jest naprawdę zagrożona, a jej przyszłość niepewna ${ }^{72}$. To przypuszczenie było dodatkowo wsparte na wynikach

${ }^{68}$ Ustawa z dnia 28 lipca 1922 o ordynacji wyborczej do Sejmu, Dz. U. z 1922 r., nr 66, poz. 590 wraz z późn. zm.

${ }^{69}$ Art. 3 Projektu Konstytucji Rzeczypospolitej Polskiej wniesiony przez klub parlamentarny SLD...

${ }^{70}$ Ibidem.

${ }^{71}$ Ibidem, art. 104, ust. 3.

${ }^{72}$ A. Hall, O wolność trzeba zabiegać, „Gazeta Wyborcza”, 28 II 1992, s. 4. 
sondażu opinii publicznej, na podstawie których w 1992 roku autorytet demokratycznych instytucji: Sejmu i Senatu, urzędu prezydenckiego i rzadu ustępował nie tylko autorytetowi Kościoła, ale także wojska i policji ${ }^{73}$.

Trudno dowieść, by autorzy projektów konstytucyjnych kierowali się przestrogą A. Halla. Natomiast to, co można stwierdzić na pewno, to fakt, iż zagadnienie kształtu przyszłych organów parlamentarnych w RP było dla przedkładających dużym wyzwaniem. Konsekwencją tego był m.in. brak wspólnego głosu, bądź podobnego do siebie konceptu wśród klubów parlamentarnych. A różnorodność rozwiązań - niekiedy mogących wydawać się zbyt oryginalnymi - sięgała w swych propozycjach nie tylko do czasów Konstytucji 3 maja, ale nawet sejmu walnego w Piotrkowie z 1493 roku.

\section{Tabela nr 2}

\begin{tabular}{|c|c|c|c|c|}
\hline \multicolumn{5}{|c|}{ Izby parlamentarne w projektach klubów poselskich 1993-1994 } \\
\hline \multirow[b]{2}{*}{ Lp. } & \multirow[b]{2}{*}{ Przedkładający } & \multicolumn{3}{|c|}{ Parlament } \\
\hline & & $\begin{array}{c}\text { Liczba izb } \\
\text { w parlamencie }\end{array}$ & Izba wyższa & Izba niższa \\
\hline 1 & $\begin{array}{l}\text { Lech Wałęsa, } \\
\text { Prezydent RP }\end{array}$ & Dwie izby & $\begin{array}{l}\text { Sejm }-444 \\
\text { posłów }\end{array}$ & $\begin{array}{c}\text { Senat }-100 \\
\text { senatorów }\end{array}$ \\
\hline 2 & Klub Parlamentarny SLD & Jedna izba & \multicolumn{2}{|c|}{ Sejm -460 posłów } \\
\hline 3 & $\begin{array}{l}\text { Komisja Konstytucyjna } \\
\text { Senatu I kadencji }\end{array}$ & Dwie izby & $\begin{array}{l}\text { Izba Poselska - } \\
444 \text { posłów }\end{array}$ & $\begin{array}{l}\text { Senat }-100 \\
\text { senatorów }\end{array}$ \\
\hline 4 & $\begin{array}{c}\text { Klub Parlamentarny PSL } \\
\text { wraz z Unią Pracy, } \\
\text { Mniejszością Niemiecką, } \\
\text { Partią Emerytów i Rencistów }\end{array}$ & Jedna izba & \multicolumn{2}{|c|}{ Sejm - 460 posłów } \\
\hline 5 & Klub Parlamentarny KPN & $\begin{array}{l}\text { Trzy stany } \\
\text { sejmujące }\end{array}$ & $\begin{array}{l}\text { Izba Poselska - } \\
444 \text { posłów }\end{array}$ & $\begin{array}{c}\text { Senat }-124 \\
\text { senatorów }\end{array}$ \\
\hline 6 & $\begin{array}{l}\text { Klub Parlamentarny } \\
\text { Unii Demokratycznej }\end{array}$ & Dwie izby & $\begin{array}{l}\text { Sejm }-460 \\
\text { posłów }\end{array}$ & $\begin{array}{c}\text { Senat }-100 \\
\text { senatorów }\end{array}$ \\
\hline 7 & $\begin{array}{l}\text { Projekt obywatelski: } \\
\text { NSZZ „Solidarność” }\end{array}$ & Dwie izby & $\begin{array}{l}\text { Sejm }-444 \\
\text { posłów }\end{array}$ & $\begin{array}{l}\text { Senat }-100 \\
\text { senatorów }\end{array}$ \\
\hline
\end{tabular}

Źródło: Opracowanie własne.

${ }^{73}$ Ibidem. 
W projekcie konstytucyjnym Lecha Wałęsy, w części odnoszącej się do kształtu przyszłego parlamentu polskiego, odnaleźć można wiele odniesień do rozwiązań konstytucyjnych z marca 1921 roku. Po pierwsze, utrzymanie dwuizbowości parlamentu w postaci: izby niższej Sejmu oraz izby wyższej Senatu. Po drugie, uznanie obu izb za organy władzy ustawodawczej w Rzeczpospolitej.

W przeciwieństwie do rozwiązań konstytucyjnych z 1921 roku, ale też z kwietnia 1935 roku, Wałęsa w swoim projekcie zawarł szczegółową informację na temat liczby posłów (444 osoby) i senatorów (100 osób). Niezbędne jest podniesienie w tym opracowaniu, że przytoczone liczby parlamentariuszy obu izb nie były obce polskim rozwiązaniom ustrojowym, gdyż tę samą kwotę wskazywała ordynacja wyborcza do Sejmu i Senatu z czasów II RP. Uzupełnieniem projektowanych rozwiązań była propozycja przeszczepienia z okresu II Rzeczpospolitej systemu wyborów posłów do Sejmu. Aż 372 posłów miało być wybranych w okręgach pięciomandatowych, a 72 posłów z tzw. listy państwowej.

Przykładem ewolucji postrzegania zasad demokracji było rozszerzenie, względem rozwiązań ustrojowych z II RP, kręgu podmiotów uprawnionych do inicjatywy ustawodawczej. W marcowej Konstytucji z 1921 roku wspomniane uprawnienie było wskazane jedynie dla dwóch podmiotów: Sejmu i Rządu. Natomiast w projekcie prezydenckim jego podmiotami byli: a) posłowie w liczbie 44 osób; b) senatorowie w liczbie 25 osób; c) Prezydent RP, d) Rada Ministrów oraz e) obywatele, co najmniej 100 tys.

Dalece interesujące i oryginalne rozwiązanie przyszłego kształtu polskiego parlamentu zostało przedstawione w projekcie KPN. Propozycją tego klubu parlamentarnego było, by w przyszłym tekście konstytucyjnym RP odciąć się od dotychczas znanego Polakom schematu parlamentarnego. Było to konsekwencją przyjętych przez autorów projektu konstytucyjnego założeń, u podłoża których znalazło się przeświadczenie o m.in. kryzysie dotychczas znanego europejskiego modelu parlamentarnego ${ }^{74}$. Dlatego Klub Parlamentarny KPN zaproponował w zamian nowy układ, który swoimi rozwiązaniami miał sięgać do czasów I Rzeczpospolitej, a dokładnie do czasu sejmu walnego w Piotrkowie z 1493 roku.

W opinii projektujących w przyszłej polskiej ustawie zasadniczej parlament winien zwać się Sejmem, który stałby na czele Rzeczpospolitej. Miałby on składać się z trzech izb obradujących, mianowicie z: Izby Poselskiej, Senatu i Prezydenta RP ${ }^{75}$. Na tak utworzonym Sejmie spoczywałaby odpowiedzialność wobec Boga, historii i narodu za losy Rzeczypospolitej $^{76}$.

Każda z wymienionych izb została wpisana w obszar uprawnień określonego rodzaju władzy. Izba Poselska, składająca się z 444 posłów, której liczba była nawiązaniem do ordynacji wyborczej z okresu II RP, miała mieć wyłączność w stanowieniu prawa. Czynitaby to z własnej inicjatywy, a nie pod czyjekolwiek dyktando ${ }^{77}$.

${ }^{74}$ Wypowiedź Leszka Moczulskiego podczas pierwszego czytania projektów konstytucyjnych na posiedzeniu Zgromadzenia Narodowego we wrześniu 1994 r., s. 35.

${ }^{75}$ Projekt Konstytucji Rzeczypospolitej Polskiej wniesiony przez klub parlamentarny KPN w dn. 30 IV 1993 r., druk ZN/5, www.bs.sejm.gov.pl/F? func=direct\&doc_number=000030488 (data dostępu 12.02.2020 r.).

${ }^{76}$ Art. 5 ust. 2 Projektu Konstytucji Rzeczypospolitej Polskiej wniesiony przez klub parlamentarny KPN...

${ }^{77}$ Wypowiedź Leszka Moczulskiego podczas pierwszego czytania..., s. 36. 
Tabela nr 3

\begin{tabular}{|c|c|c|}
\hline \multicolumn{3}{|c|}{ Inicjatywa ustawodawcza } \\
\hline \multirow[b]{3}{*}{$\begin{array}{l}\text { Konstytucja RP } \\
\text { z } 17 \text { III } 1921 \text { roku }\end{array}$} & \multicolumn{2}{|c|}{ Projekty konstytucyjne z lat 1993-1994 } \\
\hline & Projektotwórca & Źródla inicjatywy \\
\hline & $\begin{array}{l}\text { Lech Wałęsa, } \\
\text { Prezydent RP }\end{array}$ & $\begin{array}{l}\text { - posłowie w liczbie } 44 \text { osób } \\
\text { - senatorowie w liczbie } 25 \text { osób } \\
\text { - Prezydent RP } \\
\text { - Rada Ministrów } \\
\text { - obywatele, co najmniej } 100 \text { tys. }\end{array}$ \\
\hline \multirow{6}{*}{ Sejm, Rząd } & Klub Parlamentarny SLD & $\begin{array}{l}\text { - posłowie } \\
\text { - Prezydent RP } \\
\text { - Rada Ministrów } \\
\text { - Krajowa Izba Gospodarki } \\
\text { - wyborcy, co najmniej } 150 \text { tys. }\end{array}$ \\
\hline & $\begin{array}{l}\text { Komisja Konstytucyjna } \\
\text { Senatu I kadencji }\end{array}$ & $\begin{array}{l}\text { - posłowie } \\
\text { - Senat } \\
\text { - Prezydent } \\
\text { - rząd } \\
\text { - obywatele, co najmniej100 tys. }\end{array}$ \\
\hline & $\begin{array}{c}\text { Klub Parlamentarny PSL } \\
\text { wraz z Unią Pracy, } \\
\text { Mniejszością Niemiecką, } \\
\text { Partią Emerytów i Rencistów }\end{array}$ & $\begin{array}{l}\text { - Prezydent } \\
\text { - Rada Ministrów } \\
\text { - posłowie } \\
\text { - obywatele, co najmniej } 50 \text { tys. }\end{array}$ \\
\hline & Klub Parlamentarny KPN & $\begin{array}{l}\text { - Prezydent } \\
\text { - posłowie } \\
\text { - Senat } \\
\text { - obywatele, w liczbie } 100 \text { tys. }\end{array}$ \\
\hline & $\begin{array}{l}\text { Klub Parlamentarny } \\
\text { Unii Demokratycznej }\end{array}$ & $\begin{array}{l}\text { - posłowie } \\
\text { - Senat } \\
\text { - Prezydent } \\
\text { - Rada Ministrów }\end{array}$ \\
\hline & $\begin{array}{l}\text { Projekt obywatelski: } \\
\text { NSZZ „Solidarność” }\end{array}$ & $\begin{array}{l}\text { - posłowie } \\
\text { - senatorowie } \\
\text { - Prezydent } \\
\text { - rząd } \\
\text { - obywatele, co najmniej } 200 \text { tys. } \\
\text { - najbardziej reprezentatywne związki } \\
\text { zawodowe }\end{array}$ \\
\hline
\end{tabular}

Źródło: Opracowanie własne. 
Władza wykonawcza w projekcie konstytucyjnym KPN miała być reprezentowana przez urząd prezydenta. W opinii tego klubu parlamentarnego, prezydent - ze względu na swoje uwarunkowania osobowe - mógłby wykonywać obowiązki wynikające z tego rodzaju władzy w dwojaki sposób. Bądź osobiście, to znaczy bezpośrednio kierowałby rządem, bądź za pośrednictwem wskazanego przez siebie ministra. Najbardziej interesujące jest to, że wskazany przez prezydenta minister nie pełniłby funkcji premiera, a tylko pierwszego ministra ${ }^{78}$. Zadaniem takiego urzędnika miało być koordynowanie prac rządu, bycie jego przewodnikiem w imieniu prezydenta, a zatem w imieniu faktycznego konstytucyjnego organu władzy wykonawczej.

Trzecią izbą sejmujacq miał być Senat. Temu znanemu dotychczas jako druga izba legislacyjna organowi parlamentarnemu zaprojektowano absolutnie nowe funkcje, które miałyby polegać na codziennym kontrolowaniu władzy wykonawczej ${ }^{79}$. Rezultaty swoich obserwacji Senat miał obowiązek ogłaszać. Konsekwencją tak realizowanych zadań było przypisanie Senatowi uprawnienia do ogłoszenia czegoś w rodzaju votum nieufności bądź wobec określonego ministra, bądź wobec całego rządu.

Klub parlamentarny KPN, sięgając po opisane wyżej nowatorskie rozwiązania konstytucyjne, nie zaproponował w swoim projekcie ustawy zasadniczej żadnego novum w temacie inicjatywy ustawodawczej. Architekci przedstawionego projektu przypisywali prawo do wnoszenia projektów ustaw: a) posłom, b) senatorom, prezydentowi oraz d) obywatelom w liczbie nie mniej niż 100 tys.

Omawiając projektowane organy parlamentarne zawarte w propozycjach konstytucyjnych siedmiu klubów poselskich, niezbędne wydaje się sięgnąć do propozycji SDL, dla którego Konstytucja z 1921 roku była deklarowanym czynnikiem inspirującym, a niekiedy wprost źródłem rozwiązań.

Jednak by zrozumieć w pełni zawarte w projekcie konstytucyjnym SLD rozwiązania ustrojowe dla Rzeczpospolitej, istotne jest przytoczenie słów posła Jerzego Jaskierni, który czytając tekst projektu ustawy zasadniczej RP podczas posiedzenia Zgromadzenia Narodowego, zaznaczył, iż jest on m.in.: wyrazem myślenia ustrojowego wielu pokoleń ludzi lewicy ${ }^{80}$.

Pośród tzw. Artykułów podstawowych, zawierających projekt fundamentalnych zasad ustrojowych dla Rzeczpospolitej, SLD zaproponowało, by w art. 2 ust. 2 ujęta została norma konstytucyjna, której treścią było: Naród sprawuje władzę przez swych przedstawicieli wybieranych do Sejmu ${ }^{81}$. Wymienienie jedynie Sejmu, czyli jednoizbowego organu polskiego parlamentu, nie było zachowaniem przypadkowym, a świadomym. Albowiem twórcy projektu przewidywali koncepcję podziału władzy w RP na: władzę ustawodawczą - Sejm, władzę wykonawczą - rząd, i władzę sądowniczą - niezawisłe sądownictwo.

Argumentując tę propozycję, SLD wskazało na praźródło swojej decyzji, a mianowicie na tradycję myśli lewicowej, a dokładnie na PPS-owski projekt konstytucyjny, jaki był przedstawiony w czasie prac poprzedzających uchwalenie konstytucji marcowej

\footnotetext{
${ }^{78}$ Ibidem.

${ }^{79}$ Ibidem.

${ }^{80}$ Wypowiedź Jerzego Jaskierni podczas pierwszego czytania projektów konstytucyjnych, s. 43.

${ }^{81}$ Art. 2 ust. 2 Projektu Konstytucyjnego Rzeczypospolitej Polskiej wniesiony przez klub parlamentarny SLD....
} 
z 1921 roku $^{82}$. Konsekwencją tego była sugestia likwidacji - w przyszłej ustawie zasadniczej - Senatu, który w małej Konstytucji RP z 1992 roku nie posiadał dużych czy szczególnych kompetencji politycznych, i dlatego w przyszłym układzie ustrojowym RP miał być zbędny. Zdaniem posłów socjaldemokracji, jedynie w państwach federalnych dwuizbowy parlament jest słusznym, zdającym egzamin rozwiązaniem ${ }^{83}$.

Uformowany według przedstawionego projektu jednoizbowy parlament, czyli Sejm, miał być nie tylko najwyższym organem przedstawicielskim uchwalającym ustawy, ale był zaplanowany, by sprawować kontrolę nad działalnością rządu. Klub Parlamentarny SLD, przedkładający projekt konstytucyjny, nie przewidywał, by znana przed 1989 rokiem liczba posłów miała ulec zmianie.

Analizując przedstawiony projekt parlamentu odrodzonej socjaldemokracji po 1989 roku, trzeba stwierdzić, iż jej wizja daleka była od deklarowanego przez SLD czynnika inspirującego, Konstytucji marcowej z 1921 roku. Brak nawiązania do tego historycznego aktu prawnego był także widoczny w np. przyznaniu szerszemu gronu podmiotów prawa do inicjatywy ustawodawczej - czyli: posłom, rządowi, prezydentowi oraz obywatelom w liczbie co najmniej 150 tys. - jak i pozbawienie Sejmu wpływu na wybór prezydenta, co było praktykowane w II RP.

\section{Zakończenie}

Właściwie żaden projekt konstytucyjny, który został złożony w latach 90. do Komisji Konstytucyjnej Zgromadzenia Narodowego RP, nie tylko nie odwoływał się w pełni do tekstu Konstytucji marcowej z 1921 roku, ale i dla żadnego z nich nie była ona silnym źródłem inspiracji prawnoustrojowej.

Za przyczyny takiego stanu należałoby uznać co najmniej trzy powody. Po pierwsze, Konstytucja RP z 17 marca 1921 roku pisana była pośród innych wyzwań polityczno-historycznych, dla innej geograficznie społeczności Rzeczypospolitej, z odmiennym bagażem doświadczeń historycznych. Nie przez przypadek zatem ujmowała i akcentowała ona te rozwiązania, które w ocenie ówczesnych Ojców Rzeczypospolitej były niezbędne. A jej nowatorskie, liberalne zapisy konstytucyjne, czerpiące doświadczenia z m.in. rozstrzygnięć konstytucyjnych III Republiki Francji z 1875 roku, po 1989 roku były już anachronizmami, bądź też rozwiązaniami postrzeganymi za fundamentalne dla ustroju demokratycznego, np. nadanie praw wyborczych kobietom.

${ }^{82}$ W złożonym do Komisji Konstytucyjnej w maju 1919 roku projekcie konstytucyjnym, oznaczonym jako druk sejmowy 443 C, przedstawiciele Związku Parlamentarnego Polskich Socjalistów, a w tym m.in.: Mieczysław Niedziałkowski, Jędrzej Moraczewski czy Tomasz Arciszewski, zawarli projekt jednoizbowego polskiego parlamentu określonego mianem Sejmu, który miał być najwyższą władzą ustawodawczą w Rzeczpospolitej.

Warto na marginesie zaznaczyć, iż koncepcja wprowadzenia jednoizbowego parlamentu do przyszłej konstytucji odrodzonego państwa polskiego po 1918 r. nie była zmonopolizowana przez nurt socjalistyczny. Podobna inicjatywa ustrojowa została przedstawiona przez m.in. prof. Michała Bobrzyńskiego, Zygmunta Chrzanowskiego czy prof. Stanisława Wróblewskiego. Zob. więcej Wł. L. Jaworski, Prawa Państwa Polskiego. Prawo polityczne. Zeszyt II, Kraków 1919, s. 429-430, 460.

${ }^{83}$ Wypowiedź Jerzego Jaskierni podczas pierwszego czytania projektów konstytucyjnych, s. 45. 
Po drugie, doświadczenia Polski z okresu 1944-1989 były silnym i aktualnym po 1989 roku punktem odniesienia $\mathrm{w}$ relacjach społeczno-politycznych, ponad którym to okresem nie sposób było przejść obojętnie, szczególnie w takim akcie prawnym jak konstytucja. Dlatego niezbędne było zawrzeć w niej rozwiązania, które oceniająco odnosiłyby się do tego czasu i które by chroniły jednocześnie nowo powstały demokratyczny reżim polityczny w Polsce, jak choćby zakaz funkcjonowania partii politycznych promujących idee faszyzmu, nazizmu i komunizmu.

Po trzecie, czynnikiem silnie wywierającym wpływ na treść projektów konstytucyjnych w latach 90. XX wieku był polityczny rodowód, jak i partykularyzm partyjny czy instytucjonalny. Ogniskował się on bądź wokół konkretnych programów politycznych, jakie bezpośrednio oddziaływały na proponowane regulacje konstytucyjne w projektach (np. KPN, SLD czy Senatu I kadencji), bądź wokół dążeń politycznych określonej jednostki, jeśli chodzi o projekt urzędu prezydenckiego.

Współczesna Konstytucja RP z 2 IV 1997 roku nie zawiera wprost przekopiowanych rozwiązań z zapisów konstytucyjnych z marca 1921 roku. Nie oznacza to jednak, by swoją treścią pośrednio nie nawiązywała do jej spuścizny. Konstytucja III Rzeczpospolitej, podobnie jak marcowa z 1921 roku, reguluje bowiem te same wartości, jak m.in. urząd Prezydenta RP, dwuizbowość polskiego parlamentu, prawa i obowiązki obywateli czy stany nadzwyczajne, chociaż nie w pełnym znanym nam współcześnie kształcie. Oczywiście, ze względu na ewolucję np. podmiotowości suwerena czy technologiczną, obcy był Konstytucji marcowej z 1921 roku m.in. urząd Rzecznika Praw Obywatelskich czy Krajowa Rada Radiofonii i Telewizji.

Niemniej jednak tym, co wydaje się znamienne tak dla Konstytucji marcowej z 1921 roku, jak i dla Konstytucji kwietniowej z 1997 roku, a co nie wynika z ich treści, jest dążność do ochrony zawartych w nich regulacji i niedopuszczenia do ich barbaryzacji w aktualnym życiu politycznym Polski.

\section{Bibliografia}

Akty prawne:

Konstytucja RP z 2 IV 1997 r., Dz.U. 1997 nr 78 poz. 483 wraz z późn. zm.

Uchwała Senatu Rzeczpospolitej Polskiej z dnia 16 IV 1998 r. o ciagłości prawnej między II a III Rzeczpospolitq Polska, M.P. z 1998 r., nr 12, poz. 200.

Ustawa z dnia 17 marca 1921 r. - Konstytucja Rzeczypospolitej Polskiej, Dz. P. 1921 nr 44, poz. 267 z późn. zm.

Ustawa konstytucyjna z dnia 23 kwietnia 1935 r., Dz. U. RP z 24 IV 1935 r., nr 30, poz. 227.

Ustawa z dnia 28 lipca 1922 o ordynacji wyborczej do Sejmu, Dz. U. z 1922 r., nr 66, poz. 590 wraz z późn. zm.

Biała Księa Bezpieczeństwa Narodowego Rzeczypospolitej Polskiej, BBN, Warszawa 2014.

Sprawozdanie Stenograficzne z 1 posiedzenia Zgromadzenia Narodowego w dniach 21, 22, 23 września 1994 r., Warszawa 1994.

Opracowania zwarte:

Ajnenkiel A., Polskie konstytucje, Warszawa 1991.

Chruściak R., Projekty Konstytucji 1993-1997, cz. 1, Wyd. Sejmowe, Warszawa 1997. 
Dudek A., Historia polityczna Polski 1989-2015, Warszawa 2016.

Gwiżdż A., Wstęp do konstytucji, Warszawa 1997.

Jaworski W. L., Prawa Państwa Polskiego. Prawo polityczne. Zeszyt II, Kraków 1919.

Kallas M., Historia ustroju Polski X-XX w., Warszawa 1999.

Kowecki J. (opr.), Konstytucja 3 Maja 1791. Statut Zgromadzenia Przyjaciół Konstytucji, Warszawa 1981.

Kruk M. (opr.), Mała Konstytucja z komentarzem, Warszawa 1994.

Kuciński J., O Konstytucji Rzeczpospolitej Polskiej z 2 kwietnia 1997 roku, Warszawa 2014.

Łubiński P. (oprac. nauk.), Niepodległa Polska. Bezpieczeństwo i polityka w latach 1918-2018, Kraków 2018.

Makowski J., Nowe konstytucje, Warszawa 1925.

Michalik R. (red. nauk.), Implementacja zasad religijnych w sferze politycznej, Zielona Góra 2016.

Piłsudski J., Pisma zbiorowe, T. V, Warszawa 1937.

Safjan M. (red. nauk.), Konstytucja Rzeczypospolitej Polskiej. Komentarz, t. 1, C.H. Beck, Warszawa 2016.

Sarnecki P. (red. nauk.), Zarys ustroju państwowego Polski. Zagadnienia podstawowe małej Konstytucji, Kraków 1993.

Simon G., Zagadnienie spoleczne w konstytucji polskiej, Warszawa 1928.

Skorut P., Front Jedności Narodu. Od narodzin idei do upadku politycznego pozoru, Wyd. Attyka, Kraków 2015.

Sypniewski T., Rada Państwa w systemie organów władzy państwowej Polski Ludowej (1947-1989), Torun 2010.

Tuleja P. (red. nauk.), Konstytucja Rzeczypospolitej Polskiej. Komentarz, Wolters Kluwer, Warszawa 2019.

Winczorek P., Nauka o państwie, Warszawa 2005.

Witos W., Dzieła wybrane. Moje wspomnienia, t. 2, Warszawa 1990.

Artykuły:

Galarowicz J., Dlaczego nie będę głosowat na Lecha Watęsę?, „Głos”, 20-22 X 1995.

Hall A., O wolność trzeba zabiegać, „Gazeta Wyborcza”, 28 II 1992.

Konstytucja Rzeczypospolitej Polskiej. Projekt obywatelski NSZZ Solidarność, „Co tydzień Solidarność" wydanie specjalne, nr 12 (63), 1994.

Michnik A., Wasz prezydent, nasz premier. Potrzebny jest układ nowy, możliwy do zaakceptowania przez wszystkie główne sity polityczne, „Gazeta Wyborcza”, 3 VII 1989 r.

Michnik A., Czy Wałęsa zagraża demokracji?, „Gazeta Wyborcza”, 14-15 XI 1992.

Paradowska J., Król Lew. Bilans Lecha Watęsy: 1990-95, „Polityka”, 25 XI 1995.

Pawel Skorut, dr, adiunkt w Instytucie Politologii Uniwersytetu Pedagogicznego im. Komisji Edukacji Narodowej w Krakowie. W latach 2000-2014 był pracownikiem krakowskiego oddziału Instytutu Pamięci Narodowej. Autor artykułów naukowych i popularnonaukowych z zakresu bezpieczeństwa państwa, konstytucjonalizmu oraz reżimów politycznych w XX i XXI wieku. Autor i współautor trzech monografii oraz współredaktor czterech monografii zbiorowych. Współautor edycji źródeł: Dziennik Wydzielonego Oddziału Wojska Polskiego majora Henryka Dobrzańskiego ps. „Hubal” (2019). 